\title{
Review on Application of Moving Bed Biofilm Reactor (MBBR) for River Water Purification System
}

\author{
Smitha G. ${ }^{1}{ }^{1}$, Udayashankara T. H. ${ }^{2}$ \\ ${ }^{1}$ PG Student, Department of Environmental Engineering, S J College of Engineering, J S S Science \& Technology University, Mysuru, \\ Karnataka, India \\ ${ }^{2}$ Professor, Department of Environmental Engineering, S J College of Engineering, J S S Science \& Technology University, Mysuru, \\ Karnataka, India
}

\begin{abstract}
This review paper discusses the MBBR technology for urban river water purification as a robust technology. The aim of this paper is to present the MBBR technology as an alternative and efficacious method for treating different kinds of effluents under different condition. There are still present treatment technologies being studied and the results may be available in a while. The review also includes many relevant studies carried out at the laboratory and pilot scales. This review covers the important processes on basic treatment process, affecting of carrier type and influent types. However, this review concluded so far are compiled herein and reported to acquire a better outlook and insight on the theme with a view of meeting the new approach. . To this end, the most feasible technology could be the advanced biological process (bioreactor systems) including Moving Bed Biofilm Reactor (MBBR) system.
\end{abstract}

Keywords: MBBR, HRT, type of influent, kinds of biological carriers

\section{Introduction}

River pollution is an increasingly important issue for the developing countries like India mainly due to increase in urbanization and profuse discharge of untreated and/or partially treated industrial and domestic wastewaters into river. The direct discharge of domestic wastewater into the natural water bodies may lead to the water pollution which has various obstructive impacts on the environment and aquatic life [1]. In India, there is a huge gap between the production of domestic wastewater and the treatment of generated domestic wastewater. To overwhelm this concern, it is necessary to treat the domestic wastewater which has rich source of organic waste as well as the nutrients in the form of nitrate and phosphate [1]. In most of water supply systems from Yellow river, China doesn't met the tap water quality criteria by conventional drinking water treatment [2]. Through implementation of proper analysis and environmental control, polluted river can be treated biologically. Biological treatment process is considered as economic, cost-effective and environmentally sound alternative to remove the pollutants from river water.

\section{Moving bed biofilm reactor (MBBR)}

MBBR is a growing biofilm technology which has gaining attention in the wastewater treatment sector from past 20 years [3]. MBBR was established in Norway at the Norwegian University of Science and Technology in cooperation with a Norwegian company Kaldnes Miljǿteknologi (now AnoxKaldnes AS). The MBBR technology was installed in late 1980s and early 1990s. Though it is a comparatively new technology to the United States (introduced first in 1995), there were now over 400 installations worldwide in both the municipal and industrial sectors with over 36 in North America [4]. MBBRprocess developed based on combination of conventional activated sludge process and biofilter process. It involves specially designed plastic carriers called biofilm carrier for biofilm attachment. The carriers are held in suspension throughout the reactor by aeration, liquid circulation or mechanical mixing, and are kept within the reactor by means of a sieve or grill, allowing simple separation of the treated water from the biomass-containing carriers [5] and these media have the density very close to the density of water [6]. This treatment technology will be adapted for purification of polluted river where biomass or biofilm concentration increases and treatment ability. In practice, the conventional activated sludge process is accepted globally for the treatment of wastewater containing high organic matter. Excess biomass attached to the carrier gets heavy with time and is sloughed off the biofilm and carried out of the reactor with the reactor effluent. The main features which give advantage to the MBBR process over other biological wastewater treatment systems are given below as [5]:

1) Highly compact reactor - due to large biofilm surface area and highly active specialized biomass;

2) Continuous flow through process - eliminating the need for backwash and minimizing the head loss and operational complexity;

3) Multiple treatment objectives - such as BOD removal, nitrification and denitrification in a flow through series arrangement providing very simple and flexible system;

4) No sludge separation and extra space requirement because most of the active biomass is retained along with the biofilm carriers. This gives an advantage over the activated sludge process.

5) Versatility - as MBBR is suitable to retrofit into the existing tanks during up-gradation of a treatment plant.

Comparing to the other biological processes, MBBR is the one can be adapted for the polluted river water/wastewater treatment which offers compact treatment plant design to 


\section{International Journal of Science and Research (IJSR) \\ ISSN (Online): 2319-7064}

Index Copernicus Value (2016): 79.57 | Impact Factor (2015): 6.391

overcome the disadvantages of CAS process and produce good quality effluent with smaller foot print.

\section{Materials and Methods}

The carrier elements can be installed in anaerobic, anoxic reactor or aeration basin. In the MBBR process, small high density polyethylene (HDPE), polypropylene, plastic, ceramic, porous carrier elements with a large surface area are used for the growth of microorganisms within the reactor. In the reactor, agitation pattern is designed in such a manner that the upward movement of the carrier takes place across the surface of the screen. It protects from clogging so that the entire reactor will be in active biologically causing higher biomass activity. The working procedure for MBBR and carrier in reactor with biofilm growth are shown in (Figure 1) [7].

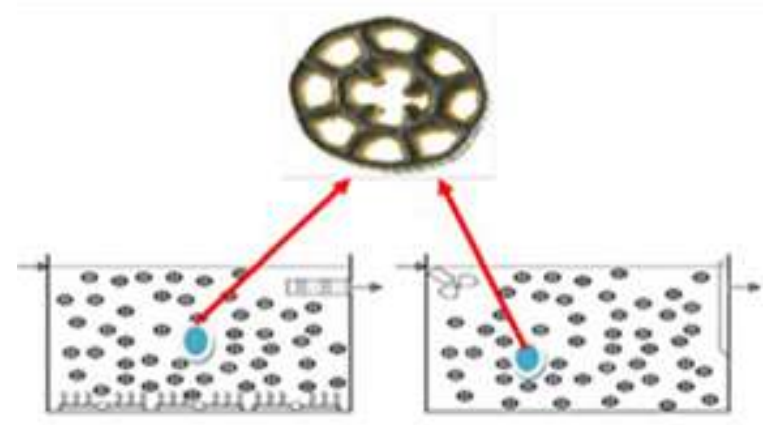

a. Acrotuc reaction

b. Amesue aud anacrotvic reaction

Figure 1.1: Shows the working procedure for MBBR and carrier in reactor with biofilm growth[7]

\section{Current Development of MBBR}

Borkar et al., 2013 conducted the lab scale study containing the 3 compartments: pre-anoxic, aerobic and post-anoxic. Pre-treated wastewater entered through inlet passes into the pre-anoxic where air supplied mechanically. Microorganism consumes the organic matter which gets attached to the media in the aeration tank. The media is continuously agitated by bubbles. Bottom of the tank contains large sized stones and upper portion with small sized stones. The wastewater gets filtered through stone beds. In last portion of tank where the bio carriers will be filled, turbulence in wastewater was created using rotors. After treatment, final treated effluent taken outside through outlet. An expected result of the study says MBBR process may be helpful to check possibility of using as an ideal and efficient option for nutrient removal from municipal wastewater. This technology may be helpful for low concentration of solids. The change in type of media carriers also plays a role in expected results in a beneficial manner.

Javid et al., 2013 carried out a laboratory study using MBBR process by constructing pilot plant at existing municipal WWTP located in Shahrak Ghods, Tehran, Iran. The pilot plant operated for one year at various conditions, carrier media filling rate was $60 \%$ of the volume with specific biofilm surface area is $500 \mathrm{~m} 2 / \mathrm{m} 3$. The removal efficiency of BOD5 and COD, the system was observed at different hydraulic retention time (HRT) of 1, 1.5, 2, 2.5, 3 and $4 \mathrm{~h}$. The results obtained from the pilot plant designate the high ability to tolerate organic loading and to remain stable at a high food to microorganism (F/M) ratio. At low HRTs the system produces the good quality effluent and leads to average BOD5 removal efficiency of around 88\% during the functioning period. The Organic Loading Rate (OLR) of a range of $0.73-3.48 \mathrm{kgBOD} 5 / \mathrm{m} 3$.day and 2.43 $11.6 \mathrm{gBOD} 5 / \mathrm{m} 2$.day was applied to the system, at which the reactor showed a good performance and stability.

Mahmoudkhani Rouhallah et al, 2012 investigated on treatment of waters around Tehran Refinery contaminated with petroleum compounds by setting laboratory scale study. During study period a $550 \mathrm{~L}$ liquid used, the reactor filled with $85 \%$ Polyurethane elements, consuming $3 \%$ of the reactor's liquid volume. While pilot study following conditions were monitored: temperature $=15$ to $25^{\circ} \mathrm{C}, \mathrm{pH}=$ 6.7 to 7.5 , dissolved oxygen $=4$ to $5 \mathrm{mg} / \mathrm{lit}$, $\mathrm{MLSS}=1400$ to $1700 \mathrm{mg} / \mathrm{L}$, Hydraulic Retention Time $(\mathrm{HRT})=240$ minutes and unlimited Solid Retention Time (SRT), suspended oil removed by oil separation system, removal efficiencies of COD, NO3-N and PO4-P for the MBBR, filtration and activated carbon was 99, 94 and 58\%, correspondingly. The average effluent results from each reactor showed that denitrification process follows the aerobic MBBR, filtration and activated carbon and in pre-denitrification system in filtration, consumed most of the biodegradable organic matter. In this pilot study, formaldehyde, phenol and total petroleum hydrocarbon (TPH) parameters were removed up to 96,79 and $94 \%$, respectively.

Sangramsingh \& Isha, 2015 conducted the study on Performance Evaluation of Moving Bed Bio-Film Reactor (MBBR) for Treatment of Domestic Wastewater. To treat domestic wastewater a pilot scale setup was used. The continuous flow allowed in operation with varying flow rate to maintain HRT 24hrs \& 48hrs. During pilot study, domestic wastewater has lower COD/BOD ratio of 2 to 3 , following conditions were monitored: temperature: $11^{\circ} \mathrm{C}$ to $35^{\circ} \mathrm{C}, \mathrm{pH}$ 6-8, constant carrier filling rate of $30 \%$. The plant was monitored up to 60 days analyzing by main parameters: BOD, COD, pH, TSS, TDS and temperature as per standards. The removal efficiencies for the parameters BOD, COD,TSS and TDS are $86 \%, 94 \%, 60 \%, 37 \%$ at HRT $24 \mathrm{hrs}$ and $90 \%, 96 \%, 65 \%, 46$ at $48 \mathrm{hrs}$ HRT respectively.

According to study carried out by Lariyah et al., 2014 on experimental comparison between MBBR and CAS for River Purification Treatment Plant. A novel parallel MBBR and CAS pilot plant was fabricated for the study. Following conditions were maintained: influent COD concentration in the range of 100 to $200 \mathrm{mg} / \mathrm{L}$, HRT- $4 \mathrm{hrs}$, flow rate from influent tank to MBBR and CAS reactors around $2.5 \mathrm{~L} / \mathrm{hr}$ or $6.94 \times 10-4 \mathrm{~L} / \mathrm{s}$ and dissolved oxygen (DO) and $\mathrm{pH}$ parameters were continuously monitored on daily basis. Weekly following parameters were also monitored: Total Suspended Solid (TSS), Volatile Suspended Solid (VSS), Chemical Oxygen Demand (COD), Biochemical Oxygen Demand (BOD), Ammonia Nitrogen (AN). The polyethylene plastic media used in MBBR reactor of specific surface area $160 \mathrm{~m} 2 / \mathrm{m} 3$ and $50 \%$ of the volume covered with the media. From the study, the results obtained in the range for DO 2.00 to $7.00 \mathrm{mg} / \mathrm{L}, \mathrm{pH}-7.0$ to 8.4 which shows the satisfactory biological process, removal efficiencies from

\section{Volume 6 Issue 12, December 2017}




\section{International Journal of Science and Research (IJSR) \\ ISSN (Online): 2319-7064}

Index Copernicus Value (2016): 79.57 | Impact Factor (2015): 6.391

MBBR system has higher $\operatorname{COD}(58 \%), \mathrm{AN}(75 \%)$ and TSS $(80 \%)$ as compared to CAS which attains only $53 \%$, $53 \%, 69 \%$ respectively and sludge produced less in MBBR related to CAS.CAS shown a little higher BOD removal rate than in MBBR - $68 \%$ compared to $65 \%$. However, overall performance of the experimental study shows better constituent removal efficiency in MBBR compared to CAS.

Mangesh \& Ashwini, 2015 conducted a feasibility study on treatment of domestic wastewater using MBBR. The lab scale setup with capacity 62 liters containing 3 compartments and performance observed for 120 days. The model operated at different rotational speeds ranging from $10 \mathrm{rpm}, 15 \mathrm{rpm}$, and $20 \mathrm{rpm}$. The maximum removal efficiency observed for the parameters BOD, COD, TS was $86 \%, 84 \%$, and $83 \%$ at rotational speed of $10 \mathrm{rpm}$ and minimum of $75 \%, 72 \%$ and $64 \%$ at rotational speed of 20 rpm.

An investigation carried out byXie, 2005 on biological pretreatment of Yellow river, China by two types of bioreactors - Bio-ceramic Filters (BF) and MBBR. In BF, ceramic particles of diameter $3-5 \mathrm{~mm}$ are filled and $50 \%$ of LT hollow ball media filled in the MBBR system. Removal rate of Total Organic Carbon (TOC) in MBBR (17.0\%) was slightly lower than $\mathrm{BF}(20.1 \%)$, average diatom removal rate in $\operatorname{MBBR}(48.6 \%)$ was similar to that in $\mathrm{BF}(47.4 \%)$, average cyanobacteria removal rate in $\mathrm{BF}(41.9 \%)$ lower than in $\operatorname{MBBR}(53.2 \%)$, average total algae removal rate in MBBR $(47.3 \%)$ higher than in $\mathrm{BF}(46.3 \%)$, average Chl-a removal rate in $\operatorname{MBBR}(35 \%)$ less than in $\mathrm{BF}(47.4 \%)$, average ammonia removal rate in $\operatorname{MBBR}(63.1 \%)$ lower than in $\mathrm{BF}($ $67.4 \%$ ), nitrate concentration in both effluents was lower than in influent which indicates biological nitrification successfully achieved without nitrate accumulation. From this study, both BF and MBBR are removed the various kinds of pollutants, organic and inorganic matter present in the river effectively. Moreover, MBBR still be a promising technology which overcomes the need for backwashing and easy management. Zhang, 2013 conducted the lab study on linking nitrifying biofilm characteristics and nitrification performance in moving-bed biofilm reactors for polluted raw water pretreatment. The experimental setup consists of 5 continuous flow MBBRs of volume 45liters and constructed in Chongshan water treatment plant. MBBR operated for 330 days. A result shows that MBBRs has good potential to remove NH4-N from polluted river water and also showed better performance than [2].

Yogita \& Mitali, 2015 conducted study on MBBR process using domestic wastewater collected from Sewage Treatment Plant, Gujarat. The experimental analysis contains 3 sewage samples collected on different days. 15 liters of sample taken in the reactor, filled with biofilm carriers made up of high density polyethylene material of 350 numbers with specific area $400 \mathrm{~m}^{2} / \mathrm{m}^{3}$ of 20 minutes of HRT and 4 hrs of settling time. Through MBBR process the removal efficiency of BOD $80-85 \%$ and COD $60-64 \%$ and concluded that this process is more efficient and effective treatment for removal BOD and COD.

Earlier studies assured that the MBBR has recognized itself as a robust and compact reactor for wastewater treatment.
The efficacy of the reactor has been demonstrated in many processes, for BOD, COD and nutrient removal. The primary advantage of the process as compared to conventional activated sludge reactors refers to its compactness. Also, system does not require sludge recirculation. The benefit over other biofilm processes is its flexibility, and a further study on this bioreactor can yield more results. Further, most studies in the field of MBBR have only focused on domestic, industrial and aquaculture wastewater. Very less study has been conducted concentrating on multiples of biological carrier specifically for river water purification.

\section{Experimental Study on MBBR}

It is important to know about foregoing experimental methodology on widespread biological carrier support in MBBR. In order to complete the study objectives, the methodology must be done in laboratory basis. A few issues need to take into consideration for laboratory experiment in water and wastewater treatment. The essential factors are design of Hydraulic Retention Time (HRT), reactor size, biomedia size, influent type and types of biological carrier. As for biological performance in biomedia, biofilm and biomass analysis and observation from previous studies also will be highlighted in this section.

\subsection{Design of HRT}

Hydraulic loading is an important factor. On the one hand, hydraulic loading directly determine HRT of the reactor, further influence the size of volume, on the other hand, hydraulic loading directly affect the removal effect in biofilm process [8] . So, selecting suitable hydraulic loading is necessary. Table 1 shows HRT and feeding value from earlier MBBR study. Many of studies tested different HRT for their experimental analysis. Most of their laboratory functioned in parallel and fed from a common feed tank by a multichannel peristaltic pump.

Table 1: Shows the HRT and feeding value from earlier study

\begin{tabular}{|c|c|c|c|c|}
\hline Process & $\begin{array}{l}\text { HRT } \\
\text { (hrs) }\end{array}$ & $\begin{array}{c}\text { Feeding value } \\
(m g / l)\end{array}$ & Location & Reference \\
\hline MBBR & $\begin{array}{c}5,10 \& \\
15\end{array}$ & COD:120-150 & Spain & $\begin{array}{c}\text { (Calderón , 2012) } \\
\text { [9] }\end{array}$ \\
\hline SBR & 4 & COD: 641 & Iran & \begin{tabular}{|l|} 
Moghaddam\&Sar \\
golzaei, 2014) [10]
\end{tabular} \\
\hline $\begin{array}{l}\text { Fixed Media } \\
\text { Submerged } \\
\text { Biofilters }\end{array}$ & 1.5 & $\begin{array}{c}\text { COD : } 270- \\
300 \\
\text { NH4-N : } 30- \\
35 \\
\text { TN }: 35-40\end{array}$ & China & $\begin{array}{c}\text { (Chundong, } \\
\text { 2012)[8] }\end{array}$ \\
\hline Hybrid MBBR & 12 & COD : 600 & Sweden & (Falås, 2013) [11] \\
\hline MBBR & 24 & $\begin{array}{c}\text { NH4-N : 40- } \\
50 \\
\end{array}$ & Italy & \begin{tabular}{|c|} 
(Bertino, \\
$2010)[12]$ \\
\end{tabular} \\
\hline Lab MBBR & $4-8$ & $\begin{array}{c}\text { COD : 500, } \\
1000,2000 \\
4000 \& 8000\end{array}$ & Turkey & $\begin{array}{c}\text { (Aygun, Nas, } \\
\text { \&Berktay, 2008) } \\
{[13]}\end{array}$ \\
\hline Real MBBR & $9 \& 12$ & $\mathrm{NH}_{3}-\mathrm{N}: 600$ & Spain & $\begin{array}{c}\text { (González- } \\
\text { Martínez et al., } \\
\text { 2013) [14] }\end{array}$ \\
\hline MBBR & $3,3.5$ & $\begin{array}{c}\text { COD: } 124 \\
\text { TSS: } 44 \\
\text { TKN: } 18\end{array}$ & $\begin{array}{l}\text { New } \\
\text { York }\end{array}$ & Johnson, 2007[15] \\
\hline
\end{tabular}

\section{Volume 6 Issue 12, December 2017}

\section{www.ijsr.net}




\section{International Journal of Science and Research (IJSR) \\ ISSN (Online): 2319-7064}

Index Copernicus Value (2016): 79.57 | Impact Factor (2015): 6.391

Low strength feeding water test generally have low HRT in range 3 to $12 \mathrm{hrs}$. High strength feeding water and anaerobic treatment occupy longer period of HRT. Nonetheless, HRT setup is subject to researcher's objective and experimental design factor.

\subsection{Types of Influent}

Influent concentration for experimental test usually are depends on the objective and expecting results. It is below a controlled range of parameter like $\mathrm{pH}, \mathrm{BOD}, \mathrm{COD}, \mathrm{TN}$ and other parameter. Table 2 shows the types of influent sources for MBBR study.

Table 2: Influent sources for MBBR experimental and pilot plant studies

\begin{tabular}{|c|c|c|c|c|}
\hline Author & Location & $\begin{array}{l}\text { Influent } \\
\text { Source }\end{array}$ & $\begin{array}{c}\text { Influent } \\
(\mathrm{mg} / \mathrm{l})\end{array}$ & Output \\
\hline $\begin{array}{c}\text { Leyva- } \\
\text { Díaz et al., } \\
2014[16]\end{array}$ & Spain & $\begin{array}{l}\text { Urban } \\
\text { WW }\end{array}$ & $\begin{array}{c}\mathrm{BOD}_{5}: \\
100-200 \\
\text { COD: } \\
200-400\end{array}$ & $\begin{array}{l}\text { Hybrid MBBR- } \\
\text { MBR indicated the } \\
\text { best performance of } \\
\text { COD and BOD5 } \\
\text { removal as compare } \\
\text { to pure MBBR- } \\
\text { MBR. }\end{array}$ \\
\hline $\begin{array}{c}\text { Gong et al., } \\
2012 \text { [17] }\end{array}$ & China & $\begin{array}{c}\text { Rural } \\
\text { domestic } \\
\text { WW }\end{array}$ & $\begin{array}{c}\text { COD: } \\
\text { 150- 300 } \\
\text { TN: } 60-90\end{array}$ & $\begin{array}{l}\text { TN was removed } \\
\text { averagely by } 69.3 \% \\
\text { and under internal } \\
\text { recycling ratio of } \\
200 \% \text { and less } \\
\text { proportions of } \\
\text { biomass assimilation } \\
\text { (less than } 3 \% \text { ). }\end{array}$ \\
\hline $\begin{array}{c}\text { Shore, } \\
\text { M'Coy, } \\
\text { Gunsch, \& } \\
\text { Deshusses, } \\
2012[18]\end{array}$ & USA & $\begin{array}{l}\text { Municipal } \\
\text { and } \\
\text { Synthetic } \\
\text { WW }\end{array}$ & $\begin{array}{c}\text { NH3-N: } \\
10-15 \\
\text { TN }: 10- \\
15\end{array}$ & $\begin{array}{l}\text { Experiment capable } \\
\text { to remove more than } \\
90 \% \text { of the influent } \\
\text { ammonia (more than } \\
19 \mathrm{mg} / \mathrm{L} \mathrm{NH3-N)} \mathrm{in} \\
\text { both the synthetic } \\
\text { and industrial } \\
\text { wastewater. }\end{array}$ \\
\hline $\begin{array}{c}\text { Pfeiffer \& } \\
\text { Wills, 2011 } \\
{[19]}\end{array}$ & USA & $\begin{array}{l}\text { Hatchery } \\
\text { Aquacult } \\
\text { ur e WW }\end{array}$ & $\begin{array}{c}\text { pH: } 7.3- \\
7.5 \\
\text { Nitrite: } \\
0.2-0.5\end{array}$ & $\begin{array}{l}\text { TAN removal rates } \\
\text { for the MB3 media } \\
\text { was the highest of } \\
\text { the three media types } \\
\text { at both the low and } \\
\text { high feed load rates } \\
\text { averaging } 12.3 \% \text { and } \\
14.4 \% \text {, respectively. }\end{array}$ \\
\hline $\begin{array}{c}\text { Clifford, } \\
\text { Forde, } \\
\text { McNamara, } \\
\text { Rodgers, \& }\end{array}$ & Ireland & $\begin{array}{c}\text { Synthetic } \\
\text { WW }\end{array}$ & $\begin{array}{l}\text { COD: } 0.6 \\
\text { TN: } 0.2 \text {, } \\
\text { and NH4- } \\
\text { N: } 0.11 \text { in }\end{array}$ & $\begin{array}{c}\text { Average removal } \\
\text { rates } 92.4 \%, 34.8 \& \text {, } \\
\text { and } 98.5 \% \text { for COD, } \\
\text { TN and NH4-N, }\end{array}$ \\
\hline
\end{tabular}

\begin{tabular}{|c|l|l|l|l|}
\hline $\begin{array}{c}\text { O'Reilly, } \\
\text { 2013 [20] }\end{array}$ & & $\mathrm{g} / \mathrm{m}^{2} /$ day & respectively \\
& & & & \\
\hline
\end{tabular}

From the above Table2, demonstrate the average value of all the influents from municipal wastewater. Average suitable influent values for experimental study are COD in range of 200-250 mg/L and BOD $100 \mathrm{mg} / \mathrm{L}$. The role of influent value is not only to make available feeding load for biomedia to treat the wastewater but also to load nutrient for attached microorganism to form a biofilm layers.

The media affords increased surface area for the biological microorganisms to attach to and grow in the aeration tanks. The increased surface area decreases the footprint of the tanks required to treat the wastewater. According to Lariyah, 2014 attached microorganism based process like MBBR are also suitable for river water purification. However, use of biofilm carriers in the MBBR reactor improved the population of autotrophic micro-organisms shows a significant role in nitrification, denitrification and biological constituent removal [21].

\subsection{Biological Carriers in MBBR}

The media used for development of biofilm are sensibly designed with high internal surface area having density slightly less than the water so that it can float easily. Themost commonly used medias forattached growth processes are; stones, clinker, sand,activated charcoal, ceramic, metals, plastic sheets, and foams. There are many types of media which can be used as a media for the microbial growth [22]. Specific surface area (SSA)is a mainfactor that promotes the biomass characteristics in water treatment and as well as the total performance of MBBR system. Table 3shows the kinds of carriers accessible in the market and being applied in laboratory and pilot plant study for MBBR system.

\subsection{Aeration rate}

In MBBR system, aeration is provided to give sufficient dissolved oxygen to the biomass and to create movement of biomedia within the reactor to avoid formation of stagnant areas [35] andalso to generate the cross flow velocity to scour the biomedia surface [17]. The high cross flow activities that are developed on the biomedia surface tend to shear off the deposited materials and thus decrease the hydraulics resistance of the fouling layer [17].

Table 3: MBBR biological carriers used in various studies

\begin{tabular}{|c|c|c|c|c|c|}
\hline Authors & Country & Types & $\begin{array}{c}\text { SSA } \\
\left(\mathrm{m}^{2} / \mathrm{m}^{3}\right)\end{array}$ & $\begin{array}{c}\text { Volume } \\
\text { concentration }\end{array}$ & \begin{tabular}{c} 
Figure \\
\hline Pfeiffer \& Wills, 2011 [19]
\end{tabular} \\
\hline USA & MB3 & 604 & - & \\
\hline P. Wang, Wang, Ai, \& Yang, 2011 [23] & China & Cageball & 300 & $40-50$ \\
\hline
\end{tabular}


International Journal of Science and Research (IJSR)

ISSN (Online): 2319-7064

Index Copernicus Value (2016): 79.57 | Impact Factor (2015): 6.391

\begin{tabular}{|c|c|c|c|c|c|}
\hline Hussain, Tat, \&Idris, 2014 [24] & Malaysi a & Cosmoball TM & 160 & 100 & \\
\hline Falås et al., 2013 [11] & Sweden & $\begin{array}{l}\text { Biofilm Chip } \\
\text { M тм }\end{array}$ & 500 & - & \\
\hline $\begin{array}{l}\text { Hoang et al., 2014; Regmi et al., 2011; Bjorn Rusten, } \\
\text { Kolkinn, \&Odegaard, } 1997 \text { [25], [26], [27] }\end{array}$ & USA & $\begin{array}{l}\text { Anodkalness } \\
\text { TM K3 }\end{array}$ & 500 & $50 \%$ & \\
\hline Authors & Country & Types & $\begin{array}{c}\mathrm{SSA} \\
(\mathrm{m} 2 / \mathrm{m} 3)\end{array}$ & $\begin{array}{c}\text { Volume } \\
\text { concentration }\end{array}$ & Figure \\
\hline Kim., 2010; Shore., 2012 [28], [18] & USA & Bioportz $^{\mathrm{TM}}$ & 576 & & \\
\hline Azimi, Hooshyari, Mehrdadi, \&Bidhendi, 2007 [29] & Iran & $\begin{array}{l}\text { Bee-Cell } \\
2000\end{array}$ & 650 & & \\
\hline Borkar et al., 2013 [4] & India & Chips & 260 & & \\
\hline Zhang et al., 2013 [30] & China & Yuhuan & 230 & & \\
\hline Bio, 2005[31] & USA & ActiveCell ${ }^{\mathrm{TM}}$ & 400 & $50-70 \%$ & \\
\hline $\begin{array}{l}\text { Aygun et al., 2008; Bertino, 2010; Calderón et al., } \\
\text { 2012; Jaroszynski, Cicek, Sparling, \&Oleszkiewicz, } \\
\text { 2011; Leyva- Díaz et al., 2013, 2014; Pfeiffer \& Wills, } \\
\text { 2011; Daniele Di Trapani, Mannina, Torregrossa, } \\
\text { \&Viviani, } 2010 \text { [9], [12],[13], [16], [32], [33], [19], } \\
\text { [34] }\end{array}$ & $\begin{array}{l}\text { USA, } \\
\text { Turkey, } \\
\text { Canada, } \\
\text { Spain \& } \\
\text { Italy }\end{array}$ & $\begin{array}{l}\text { Anodkalnes } \\
\mathrm{s}^{\mathrm{TM}} \mathrm{K} 1\end{array}$ & 500 & $50-70 \%$ & \\
\hline
\end{tabular}

Aygun et al., 2008; Bertino, 2010; Calderón et al., 2012; Jaroszynski, Cicek, Sparling, \&Oleszkiewicz, 2011; LeyvaDíaz et al., 2013, 2014; Pfeiffer \& Wills, 2011; Daniele Di Trapani, Mannina, Torregrossa, \&Viviani, 2010 [9], [12],[13], [16], [32], [33], [19], [34] USA, Turkey, Canada, Spain \& Italy Anodkalness ${ }^{\mathrm{TM}} \mathrm{K} 1500$ 50- 70\%

An optimum value of air flow rate was recognized beyond which further increase had no influence. The similar occurrence was also verified by some researchers [17]. Wang (2012) examined the influence of hydrodynamic on biomedia and determined that the treatment filtration rate abruptly increased at aeration intensity below the critical aeration intensity.

\section{Conclusion}

MBBR is gaining importance around the world. It is a leading technology in wastewater treatment as this system can operate at smaller footprints and give higher removal efficiency. The MBBR performed to be an effective process for removing most of the pollutants at different HRTs. Nowadays, there are different types of biomedia used in river water purification technologies which are locally available and international water industry market, and the kinds of biomedia can be characterized by considering the types of treatment system. Based on the certain treatment conditions, different types of biomedia shown their unique performance. Other than from biomedia removal efficacy and physical characteristics at the allocated design flow, another important feature that influence the decision in selection of biological carriers for MBBR are frequency of

\title{
Volume 6 Issue 12, December 2017
}

\author{
www.ijsr.net
}




\section{International Journal of Science and Research (IJSR) \\ ISSN (Online): 2319-7064}

Index Copernicus Value (2016): 79.57 | Impact Factor (2015): 6.391

maintenance and cost. Biomedia should be able to accommodate a habitation for the growth of the attached microorganism which is called biofilm layer, either fixed or freely moving inside the river purification system. Based on preceding studies, biomedia in MBBR and IFAS have been broadly tested only for domestic sewage or industrial wastewater together with aquaculture wastewater. Though, methodologies of this kind carry with them a various well known limitations. For local tropical river condition, there are no precise studies which compare differences between biomedia physic-chemical and biological performance for river water treatment plant have been carried out. However, this review concluded so far are compiled herein and reported to acquire a better outlook and insight on the theme with a view of meeting the new approach. To this end, the most feasible technology could be the advanced biological process including Moving Bed Biofilm Reactor (MBBR) system.

\section{Acknowledgement}

The author is thankful to Dr. Udayashankara T.H., Professor, Department of Environmental Engineering, Sri Jayachamarajendra College of Engineering, JSS Science and Technology University, Mysuru- 570 006, Karnataka, India for the prodigious support.

\section{References}

[1] Sangramsingh A. Thakur, Isha P. Khedikar, 2015, "Performance Evaluation of Moving Bed Bio-Film Reactor (MBBR) for Treatment of Domestic Wastewater, IJSR, Vol 6, pp 973-976.

[2] XIE Shu-guang, Tang Xiao-yan, WU Wei-zhong, WEN Dong-hui, WANG Zhan-sheng, 2005, "Biological pretreatment of Yellow River Water", Journal of Environmental Sciences, Vol 17, pp 557-561.

[3] João P. Bassin, Marcia Dezotti, Geraldo L. Sant'Anna Jr., 2011, "Nitrification of industrial and domestic saline wastewaters in moving bed biofilm reactor and sequencing batch reactor", Journal of Hazardous material, Vol 185, pp 242-248.

[4] Borkar R.P, Gulhane M.L, and Kotangale A.J, 2013, "Moving Bed Biofilm Reactor - A New Perspective in Wastewater Treatment", IOSR-JESTFT, Vol 6, pp 1521

[5] D.J. Gapes, J. Keller, 2009, "Impact of oxygen mass transfer on nitrification reactions in suspended carrier reactor biofilms", Process Biochemistry, Vol 44, pp 4353, https://www.journals.elsevier.com/processbiochemistry

[6] M S Lariyah, H A Mohiyaden, G Hayder, A Hussein, H Basri, A F Sabri, MN Noh, 2016, "Application of Moving Bed Biofilm Reactor (MBBR) and Integrated Fixed Activated Sludge (IFAS) for Biological River Water PurificationSystem: A Short Review", International Conference on Advances in Renewable Energy and Technologies (ICARET), Vol 36, pp 1-16.

[7] WisamSabeeh Al-Rekabi, 2015, " Mechanisms of Nutrient Removal in Moving Bed Biofilm Reactors", International Journal of Scientific \& Engineering Research, Vol 6, Issue 1, pp 497-517, www.iosrjournals.org.
[8] J. Chundong, X. Zhi, F. Qingzhi, G. Haiyan, and Y. Guohui, 2012, "Treatment of Synthetic Wastewater in a Pre-Denitrification Biofilm Reactor Packed with Polyurethane Media," Energy Procedia, Vol. 16, pp. 1642-1649.

[9] K. Calderón, J. Martín-Pascual, J. M. Poyatos, B. Rodelas, A. González-Martínez, and J. González-López, 2012, "Comparative analysis of the bacterial diversity in a lab-scale moving bed biofilm reactor (MBBR) applied to treat urban wastewater under different operational conditions.," Bioresource. Technology, Vol. 121, pp. 119-126.

[10]A. HedayatiMoghaddam and J. Sargolzaei, 2014, "Biofilm development on normal and modified surface in a hybrid SBR-based bioreactor," J. Taiwan Inst. Chem. Eng, pp 1-7.

[11]P. Falås, P. Longrée, J. la Cour Jansen, H. Siegrist, J. Hollender, and A. Joss, 2013, "Micropollutant removal by attached and suspended growth in a hybrid biofilmactivated sludge process.," Water Res., Vol 47, no. 13, pp 4498-4506.

[12]A. Bertino, 2010, "Study on one-stage Partial Nitritation-Anammox process in Moving Bed Biofilm Reactors: a sustainable nitrogen removal," Royal Institute of Technology.

[13] A. Aygun, B. Nas, and A. Berktay, 2008, "Influence of High Organic Loading Rates on COD Removal and Sludge Production in Moving Bed Biofilm Reactor," Environ. Eng. Sci., Vol 25, no. 9, pp. 1311-1316.

[14] A González-Martínez, K. Calderón, A. Albuquerque, E. Hontoria, J. González-López, I. M. Guisado, and F. Osorio, 2013, "Biological and technical study of a partial-SHARON reactor at laboratory scale: effect of hydraulic retention time.," Bioprocess Biosyst. Eng., Vol 36, no. 2, pp. 173-184.

[15] Terry L. Johnson, Andrew Shaw , Heather Phillips, Nancy Choi, Thomas Lauro, Ralph Butler,LeahRadko, 2007, "A Pilot-Scale Comparison of IFAS and MBBR to Achieve Very Low Total Nitrogen Concentrations", Water practice, Vol 1, no 5, pp1-14.

[16] J. C. Leyva-Díaz, J. Martín-Pascual, M. M. Muñío, J. González-López, E. Hontoria, and J. M. Poyatos, 2014, "Comparative kinetics of hybrid and pure moving bed reactor-membrane bioreactors," Ecol. Eng., Vol 70, pp 227-234.

[17] L. Gong, L. Jun, Q. Yang, S. Wang, B. Ma, and Y. Peng, 2012, "Biomass characteristics and simultaneous nitrification-denitrification under long sludge retention time in an integrated reactor treating rural domestic sewage," Bioresource Technology, Vol 119, pp. 277 284.

[18] J. L. Shore, W. S. M'Coy, C. K. Gunsch, and M. A. Deshusses, 2012, "Application of a moving bed biofilm reactor for tertiary ammonia treatment in high temperature industrial wastewater," Bioresource. Technology, Vol 112, pp. 51-60.

[19] T. J. Pfeiffer and P. S. Wills, 2011, "Evaluation of three types of structured floating plastic media in moving bed biofilters for total ammonia nitrogen removal in a low salinity hatchery recirculating aquaculture system," Aquacultural Engineering, Vol 45, no. 2, pp 51-59.

[20]E. Clifford, P. Forde, S. McNamara, M. Rodgers, and E. O'Reilly, 2013, "Performance of Air Suction Flow 


\section{International Journal of Science and Research (IJSR) \\ ISSN (Online): 2319-7064 \\ Index Copernicus Value (2016): 79.57 | Impact Factor (2015): 6.391}

Biofilm Reactor in Treating Municipal-Strength Wastewater," J. Environ. Eng., Vol 139, no. 6, pp 864872.

[21] LariyahMohdSidek, HairunAishahMohiyaden, HidayahBasri, GasimHayder Ahmad Salih, Ahmad Hussein Birima, Zuraidah Ali, Ahmad FauzanMohdSabri and Md. Nasir, 2014, "Experimental Comparison between MBBR and CAS for River Purification Treatment Plant", International Conference On Global Sustainability And Chemical Engineering (ICGSE).

[22]A. Shrestha, 2013, "Specific Moving Bed Biofilm Reactor in Nutrient Removal from Municipal Wastewater," University of Sydney.

[23]P. Wang, C. Wang, X.-Y. Ai, and C.-Q. Yang, 2011, "Biofilm characteristics of globular biofilter in the ecological spur-dike and water quality improvement effect on Wangyu River," International Conference on Electronics, Communications and Control, no. 9-11, pp. 3598-3603

[24] S. A. Hussain, T. H. Tat, and A. Idris, 2014, "Numerical study of fluid flow across multiple Cosmo ball," Int. J. Nano Biomaterials., Vol 5, no. 1, p 89.

[25] V. Hoang, R. Delatolla, T. Abujamel, W. Mottawea, A. Gadbois, E. Laflamme, and A. Stintzi, 2014, "Nitrifying moving bed biofilm reactor (MBBR) biofilm and biomass response to long term exposure to $1{ }^{\circ} \mathrm{C}$," Water Resources, Vol 49, pp. 215-224.

[26]P. Regmi, W. Thomas, G. Schafran, C. Bott, B. Rutherford, and D. Waltrip, 2011, "Nitrogen removal assessment through nitrification rates and media biofilm accumulation in an IFAS process demonstration study.," Water Resources, Vol 45, no. 20, pp. 6699-6708.

[27]B. Rusten, O. Kolkinn, and H. Odegaard, 1997, "Moving bed biofilm reactors and chemical precipitation for high efficiency treatment of wastewater from small communities," Water Sci. Technol., Vol 35, no. 6 , pp 71-79.

[28] H.S. Kim, J. W. Gellner, J. P. Boltz, R. G. Freudenberg, C. K. Gunsch, and A. J. Schuler, 2010,"Effects of integrated fixed film activated sludge media on activated sludge settling in biological nutrient removal systems.," Water Res., Vol 44, no. 5, pp 1553-1561.

[29] A. A. Azimi, B. Hooshyari, N. Mehrdadi, and G. H. N. Bidhendi, 2007, "Enhanced COD and nutrient removal efficiency in a hybrid integrated fixed film activated sludge process," Iran. J. Sci. Technol., Vol 31, pp 523533.

[30] S. Zhang, Y. Wang, W. He, M. Wu, M. Xing, J. Yang, N. Gao, and D. Yin, 2013, "Responses of biofilm characteristics to variations in temperature and $\mathrm{NH} 4(+)-$ $\mathrm{N}$ loading in a moving-bed biofilm reactor treating micro-polluted raw water," Bioresource Technology, Vol 131, pp 365-373.

[31]H. Bio, 2005, "Applications of Technologies Wastewater Technologies." Houston, Texas, p 40.

[32]L. W. Jaroszynski, N. Cicek, R. Sparling, and J. a Oleszkiewicz, 2011, "Importance of the operating $\mathrm{pH}$ in maintaining the stability of anoxic ammonium oxidation (anammox) activity in moving bed biofilm reactors.," Bioresource Technology, Vol 102, no. 14, pp 70517056.
[33] J. C. Leyva-Díaz, K. Calderón, F. a. Rodríguez, J. González-López, E. Hontoria, and J. M. Poyatos, 2013, "Comparative kinetic study between moving bed biofilm reactor-membrane bioreactor and membrane bioreactor systems and their influence on organic matter and nutrients removal," Biochemical Engineering Journal, Vol 77, pp 28-40.

[34] D. Di Trapani, G. Mannina, M. Torregrossa, and G. Viviani, 2010, "Quantification of kinetic parameters for heterotrophic bacteria via respirometry in a hybrid reactor," Water Science Technology, Vol 61, no. 7, pp $1757-1766$

[35] S. Zhang, Y. Wang, W. He, M. Wu, M. Xing, J. Yang, N. Gao, and M. Pan, 2014 "Impacts of temperature and nitrifying community on nitrification kinetics in a moving-bed biofilm reactor treating polluted raw water," Chemical Engineering Journal, Vol 236, pp $242-250$.

[36] J. Wang, X. D. Liu, and J. Lu, 2012, "Urban River Pollution Control and Remediation," Procedia Environmental Science, Vol 13, pp 1856-1862.

[37] Javid A.H., Hassani A. H., Ghanbari B., and Yaghmaeian K., 2013, "Feasibility of Utilizing Moving Bed Biofilm Reactor to Upgrade and Retrofit Municipal Wastewater Treatment Plants", Int. J. Environ. Res., Vol 7(4), pp 963-972, ISSN: 1735-6865.

[38] RouhallahMahmoudkhani ， Akbar MokhtariAzar , AlirezaDehghani and HosseinGhoreishi 2012, "Treatment of Contaminated Waters with Petroleum by Moving Bed Biofilm Reactor (MBBR)", International Conference on Life Science and Engineering IPCBEE, Vol 45, pp 12-16.

[39] MangeshGulhane, AshwiniIngale, 2015, "Moving Bed Biofilm Reactor: A Best Option for Wastewater Treatment", International Journal for Scientific Research \& Development (IJSRD), Vol. 3, Issue 01, pp 1094-1096.

[40] Shuangfu Zhang, Yayi Wang , Weitao He, Meiyan Xing, Min Wu, Jian Yang, NaiyunGao, Guangyao Sheng, Daqiang Yin, Shanhu Liu, 2013, "Linking nitrifying biofilm characteristics and nitrification performance in moving-bed biofilm reactors for polluted raw water pretreatment", Bio-resource Technology, Vol 146, pp 416-425.

[41] Yogita Sindhi, Mitali J. Shah,2015, "Lab Scale Study on Moving Bed Biofilm Reactor- An Effective Perspective in Biological Wastewater Treatment", International Journal of Advanced Research in Engineering, Science and Management (IJARESM), Vol 1, Issue 5, pp 1-7, ISSN : 2394-1766, www.ijaresm.net 